\title{
Нейромережева система моніторингу показників шкідливих викидів суднового парового котла
}

Михайленко В.С. ${ }^{1}$, Лещенко В.В. ${ }^{2}$, Сакали С.М. ${ }^{3}$, Харченко Р.Ю. ${ }^{4}$ НУ «Одеська морська академія», м. Одеса, Україна vladmihailen@gmail.com¹,1vvlvv@ukr.net ${ }^{2}$, sakaly11201@gmail.com.ua, ${ }^{3}$ romannn30@gmail.com ${ }^{4}$,

\section{Neural network system for monitoring indicators of harmful emissions of a ship's steam boiler}

\author{
Vladislav Mikhailenko ${ }^{1}$, Valery Leshchenko ${ }^{2}$, Sergey Sakaly ${ }^{3}$, \\ Roman Kharchenko \\ NU "Odessa Maritime Academy", Odessa, Ukraine \\ vladmihailen@gmail.com",1vvlvv@ukr.net ${ }^{2}$, \\ sakaly11201@gmail.com.ua ${ }^{3}$,romannn30@gmail.com ${ }^{4}$
}

Резюме - Поставлено завдання розробки ефективної нейромережевий системи моніторингу показників шкідливих викидів димових газів суднового котла в атмосферу. 3 метою навчання нейронної мережі проведені експерименти на мазутному водотрубному паровому котлі типу ГМ-50М. Моделювання нейромережевий системи моніторинуу на прикладі найбільш поширених теплових режимів котла показало можливість зниження вмісту икідливих викидів на 25 \% в порівнянні $з$ типовою системою управління процесом горіння рідкого палива.

Abstract - The factory for the development of an effective neurogauge system and monitoring of indicators of high-pressure wikis of the ship's boiler gases into the atmosphere was supplied. The modeling of neurorecording systems and monitoring, on the basis of the most advanced thermal regimes of the boiler, showed the possibility of decreasing, instead of high-speed ones, by $25 \%$ in relation to the standard control system for the process of burning a small fire.

DOI: 10.31653/1819-3293-2020-1-26-41-57 
Проблема захисту повітряного басейну стоїть дуже гостро. Неорганічні i органічні сполуки, що входять до складу відпрацьованих газів транспортних засобів, в тому числі і в суднових енергетичних установках (СЕУ), надають комплексний шкідливий вплив на навколишнє середовище. До найбільш небезпечних речовин можна віднести викиди оксидів азоту $\left(\mathrm{NO}_{\mathrm{x}}\right)$. Токсичність $\mathrm{NO}_{\mathrm{x}}$ перевищує токсичність більшості інших шкідливих компонентів, тому проблема зниження викидів оксидів азоту в атмосферу має важливе значення в справі охорони навколишнього середовища [1]. Боротьба 3 викидами $\mathrm{NO}_{\mathrm{x}}$ ускладнюється тим, що їх максимальна поява відповідає режиму найбільш ефективного згоряння палива, тому методи скорочення викидів $\mathrm{NO}_{\mathrm{x}}$ не повинні призводити до зниження інтенсивності робочих процесів агрегатів СЕУ.

В даний час діє цілий ряд підходів щодо зменшення концентрації $\mathrm{NO}_{\mathrm{x}}$ в димових газах агрегатів СЕУ: первинні методи, які полягають в придушенні утворення $\mathrm{NO}_{\mathrm{x}}$ в топках котлів або камерах згоряння дизелів і вторинні методи зниження викидів $\mathrm{NO}_{\mathrm{x}}$, які полягають в обробці димових газів після котла або дизеля $[2,3]$. Незважаючи на великий обсяг виконаних досліджень, більшість робіт спрямовано на зниження викидів оксидів азоту методами селективного каталітичного і некаталітичного відновлення оксидів азоту [2]. Зазначені методи хоча i забезпечують високу ступінь очищення димових газів, але пов'язані зі значними фінансовими витратами i засновані на використанні небезпечних хімічних реагентів. Тому проблема розробки і впровадження на суднах нових, економічно відносно недорогих та екологічно ефективних методів очищення відпрацьованих газів суднових котлів від оксидів азоту є актуальною.

Для аналізу ефективності процесу горіння мазутного палива в паровому котлі і вмісту шкідливих викидів в атмосферу, проведена серія натурних експеримент на водотрубному паровому котлі. План експериментів був аналогічний плану методики налагодження систем управління суднових парових котлів [4].

У процесі проведених замірів при налаштування теплового режиму водотрубних парових котлів компанії [5] було встановлено, що при навантаженні водотрубного парогенератора марки ГМ-50, що дорівнює 0,8 від номінальної, і при коефіцієнті надлишку повітря $\alpha=1,4$, вміст оксидів азоту склало $77 \mathrm{Mг} / \mathrm{M}^{3}$ при його коливанні $\left(20-80 \mathrm{M \Gamma} / \mathrm{M}^{3}\right)$ в залежності від значення $\alpha$ і навантаження.

При проведенні експлуатаційних випробувань використовувались штатні прилади котла. Додатково застосовувались газоаналізатори 
ДГП-ЗМ та переносні автоматичні цифрові газоаналізатори типу "Testo-Term" с похибкою вимірювань 2,5 \% [6].

Слід зазначити, що коефіцієнт надлишку повітря $\alpha-$ відношення дійсної кількості повітря $V_{g}$, поданого в топку котла до теоретично необхідного для горіння $V^{\circ}$, визначається [7]:

$$
\alpha=\frac{V_{g}}{V^{o}} .
$$

Значення $\alpha$ залежить від складу і виду палива, топкового режиму, ступеня досконалості змішування палива 3 повітрям і т.п. Якщо відомий хімічний склад газів, одержуваних при згорянні палива, коефіцієнт надлишку повітря може бути визначений за "азотної" формулою, яка для випадку повного горіння палива записується таким чином [7]:

$$
\alpha=\frac{N_{2}}{N_{2}-3,76 \mathrm{O}_{2}},
$$

де $N_{2}$ - вміст азоту в продуктах горіння, \%, - звідси слідує, що зі збільшенням вмісту кисню у вихідних газах величина азоту також зростає.

Можна відзначити, що аналіз значень $\mathrm{CO}_{2}$ може бути використаний як альтернатива значенням $\mathrm{O}_{2}$ у вихідних газах парогенератора у випадках, коли в системі управління процесом горіння несправний киснемір.

Таким чином, для зниження вмісту шкідливих викидів СПУ необхідно зниження значення $\alpha$. Відповідно до загальноприйнятої методики налагодження суднових парогенераторів [4], $\alpha$ може приймати значення [7]:

для СПУ з високою паровою продуктивністю 1,03 - 1,25;

для СПУ з малою і середньою паровою продуктивністю (до 50 т / год) $1,01-1,5$.

Вимірювання швидкості газу в газоході здійснювалося за допомогою пневмометричні трубок типу Піто-Прандтля і мікроманометрі. Подальший розрахунок швидкості газу $v($ м/с) здійснено за формулою:

$$
v=\sqrt{\frac{2 P_{d}}{\rho}},
$$

де $\rho$ - щільність газу при робочих умовах, кг $/ \mathrm{M}^{3}$.

Динамічний тиск вихідного газу

$$
P_{d}=p b \kappa_{\mathrm{T}}
$$

де $p$ - показання за шкалою микроманометра, Па; $b$ - коефіцієнт, що залежить від кута нахилу вимірювальної трубки микроманометра (наводиться в паспортних даних засобів вимірювання); $\kappa_{\mathrm{T}}-$ коефіцієнт 
напірної трубки, який визначається при їі перевірці. Для трубок конструкції Піто-Прандтля $\kappa_{\mathrm{T}}=0,9-1,0$.

При цьому, для визначення розрахункового значення швидкості димових газів використовувалася формула:

$$
v_{p}=\frac{B_{p} V_{g}(T+273)}{F \cdot 273},
$$

де $B_{p}$ - витрата палива, кг / год (сірчистий мазут); $V_{g}$ - об'єм димових газів, $\mathrm{m}^{3} ; T$ - температура продуктів згоряння ${ }^{\circ} \mathrm{C} ; F$ - площа перерізу газоходу, $\mathrm{m}^{2}$.

Згідно (1) збільшення швидкості і об'єму димових газів з незмінною витратою палива призведе до зменшення температури димових газів. Таким чином, залежність (1) можна враховувати для процесу зниження вмісту шкідливих викидів.

Залежно від механізму утворення оксиду азоту в процесі горіння палива розрізняють "термічні", "швидкі" та "паливні" оксиди азоту.

Термін "термічний" оксид азоту отримав за те, що в основі механізму його утворення лежить залежність концентрації NO від температури в зоні горіння. Найбільш повно сукупність явищ, що відбуваються при окисленні азоту в топках теплогенераторів може бути описана на підставі теорії Я.Б. Зельдовича і М.М. Семенова [8]. Умовою окислення азоту повітря $є$ дисоціація молекули кисню повітря під впливом високих температур, що йде з поглинанням теплоти:

$$
\mathrm{O}_{2} \Leftrightarrow \mathrm{O}+\mathrm{O}-495 \text { кДж/моль. }
$$

Атомарний кисень реагує з молекулою азоту, а що утворився в результаті ендотермічної реакції атомарний азот, вступає в екзотермічну реакцію з молекулярним киснем:

$$
\begin{gathered}
\mathrm{N}_{2}+\mathrm{O} \Leftrightarrow \mathrm{NO}+\mathrm{N}-314 \text { кДж/моль; } \\
\mathrm{O}_{2}+\mathrm{N} \Leftrightarrow \mathrm{NO}+\mathrm{O}+134 \text { кДж/моль; } \\
\mathrm{N}_{2}+\mathrm{O}_{2} \Leftrightarrow 2 \mathrm{NO}-180 \text { кДж/моль. }
\end{gathered}
$$

Зміна концентрації оксиду азоту в одиницю часу визначається:

$$
d \mathrm{C}_{\mathrm{NO}} / d \mathrm{t} \Leftrightarrow k_{1} \times \mathrm{C}_{\mathrm{N} 2} \times \mathrm{C}_{\mathrm{O} 2}-k_{2} \times\left[\mathrm{C}_{\mathrm{NO}}\right]^{2} .
$$

де $\mathrm{C}_{\mathrm{N} 2}, \mathrm{C}_{\mathrm{O} 2}$ - відповідно концентрації $\mathrm{N}_{2}$ i $\mathrm{O}_{2}$, об. \%; $\mathrm{C}_{\mathrm{NO}}$ - рівноважна концентрація NO, об. \% (тобто концентрація, що виходить при необмеженого боргом протікання реакціï); $k_{1}, k_{2}$ - константи швидкості прямих і зворотних реакцій.

Рівноважна концентрація NO виходить з виразу (2) при $d \mathrm{C}_{\mathrm{NO}} / d t=$ 0 при відомих константах швидкостей реакцій

$$
\left[C_{N O}\right]=4,6 \times \sqrt{C_{O 2} \times C_{N 2}} \times \exp (-21500 /(R \times T)) .
$$


3 аналізу цієї формули випливає, що рівноважна концентрація оксиду азоту зростає зі збільшенням температури і концентрації кисню (концентрація азоту змінюється мало). Рівноважна концентрація NO понад 1 г/ $\mathrm{M}^{3}$ має місце при температурі понад $1600{ }^{\circ} \mathrm{C}$ і подвоюється при підвищенні температури на кожні $200 \ldots 250{ }^{\circ} \mathrm{C}$.

В процесі експериментів (рис. 1 - 5) встановлено, що при зниженні теплового навантаження котла до 0,5 і стабілізації $\alpha-$ зміст $\mathrm{NO}_{\mathrm{x}}$ у вихідних газах знижується, в середньому, до 30 \%. Також встановлено, що зниження швидкості проходження димових газів на 1 м/с (за рахунок плавного збільшення обертів двигуна димососа) знижує вміст $\mathrm{NO}_{\mathrm{x}}$ в середньому на $10 \mathrm{Mг} / \mathrm{m}^{3}$ у порівнянні з димососом рециркуляції, працюючим на одній швидкості. Також, в ході експериментів встановлено і зростання вмісту $\mathrm{SO}_{x}$ у вихідних газах при збільшенні $\alpha$. Схожа динаміка зазначених спостережень простежується і в [2], що $є$ підтвердженням зазначених вище залежностей.

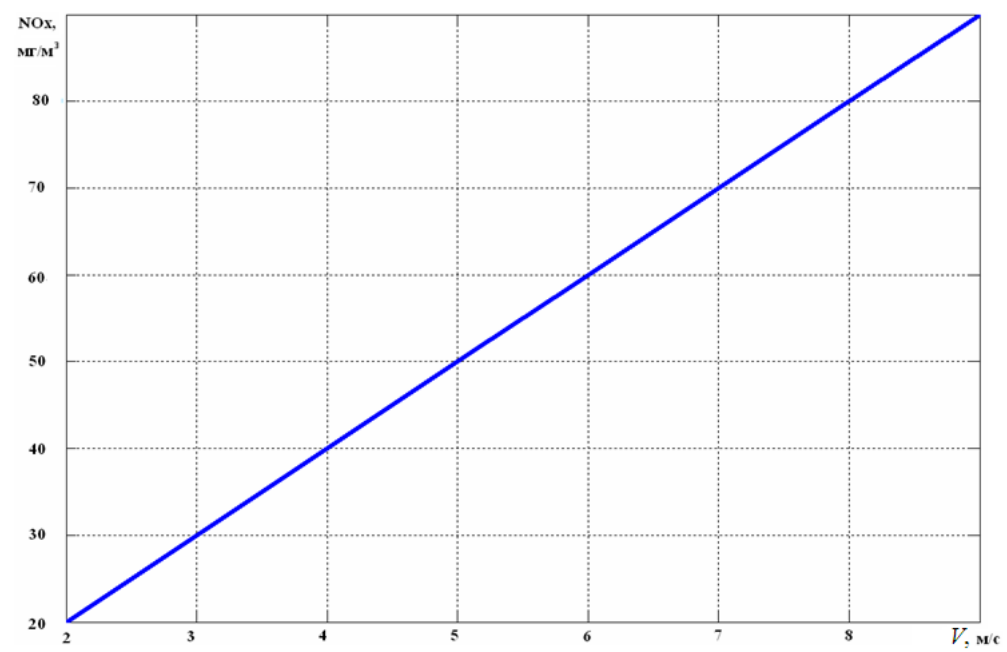

Рис. 1. Залежність вмісту $\mathrm{NO}_{\mathrm{x}}$ парового котла ГМ-50 від швидкості вихідних газів

За результатами отриманих даних можна зробити висновок, що 3 ростом теплової потужності, тобто витрати палива, підвищується і середній температурний рівень як в топці, так і в факелі. Причому між температурою в топці і тепловою потужністю агрегату існує логарифмічна залежність. Як показано вище концентрація оксиду азоту екс- 
поненціально залежить від температури в зоні горіння. Численні дослідження показали, що між концентрацією NO і тепловою потужністю агрегату в діапазоні робочих навантажень існує лінійна залежність. Це може бути пояснено тим, що логарифмічна і експоненціальна залежності вироджуються в пряму лінію. Однак при навантаженнях, близьких до максимальних, тобто при досягненні максимальної температури, спостерігається стабілізація концентрація оксиду азоту (рис. 4).

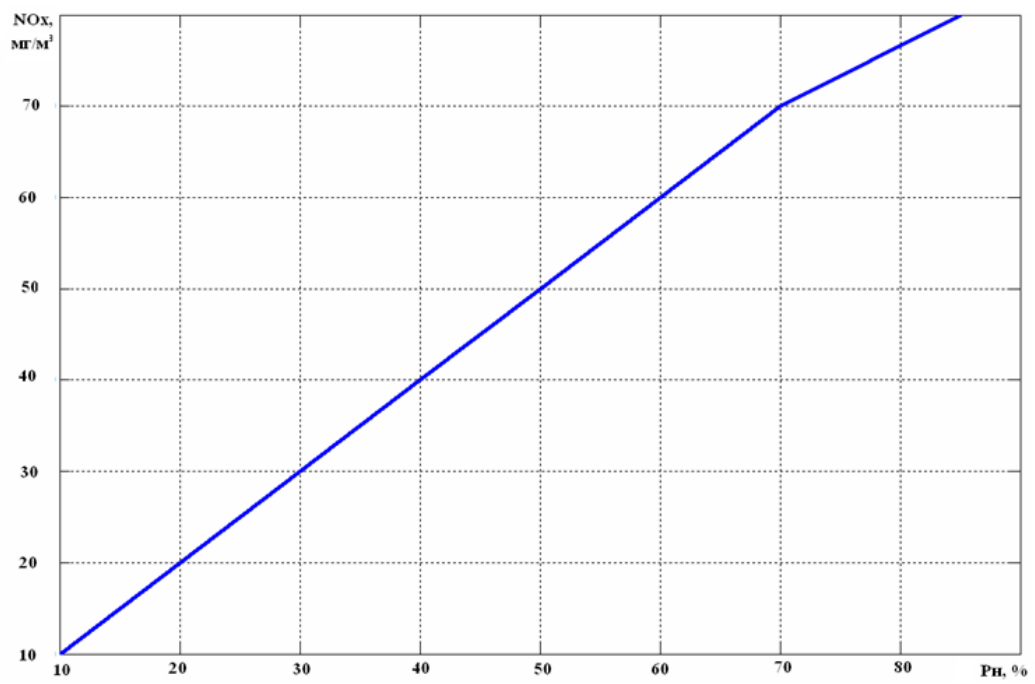

Рис. 2. Залежність вмісту $\mathrm{NO}_{\mathrm{x}}$ в димових газах від теплового навантаження котла ГМ-50

При збільшенні коефіцієнта надлишку повітря в зоні реакції зростає як концентрація $\mathrm{O}_{2}$, так $\mathrm{i} \mathrm{N}_{2}$. Проте зростання виходу оксиду азоту зі збільшенням коефіцієнта надлишку повітря спостерігається до значень, близьких до 1,5 , а потім настає зменшення його концентрації (рис. 4.). Це може бути пояснено таким чином. При спалюванні палива в топку подається не гомогенна суміш палива 3 повітрям. При $(\alpha<$ $1,5)$ концентрації $\mathrm{O}_{2}$ в локальних зонах не вистачає на протікання реакції окислення азоту. Кисень в першу чергу витрачається на окислення вуглеводів в результаті протікання ланцюгових реакцій горіння. При збільшенні $\alpha$ до 1,5 зростає як частка вільного $\mathrm{O}_{2}$, так і температура в зоні горіння внаслідок більш повного вигоряння вуглеводів. 


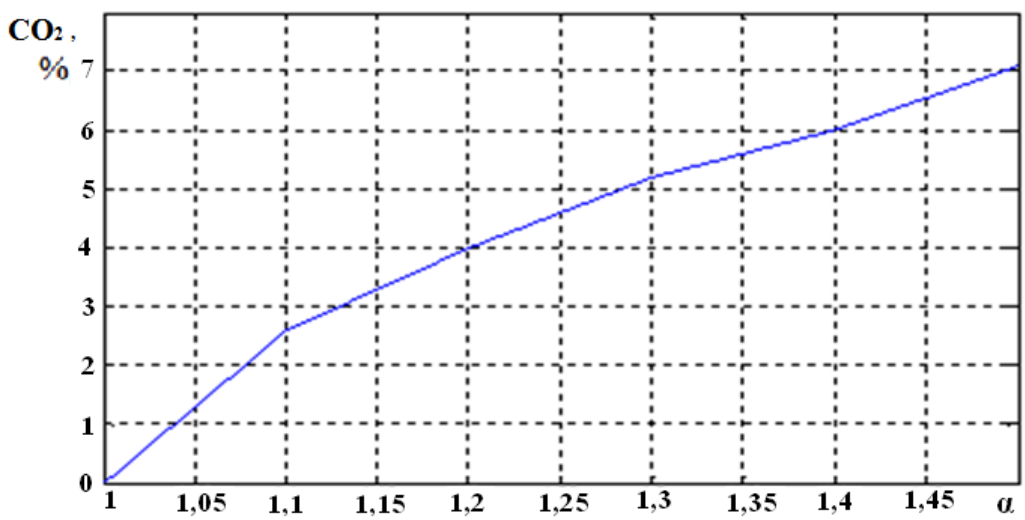

Рис. 3. Залежність вмісту $\mathrm{CO}_{2}$ в вихідних газах СПУ від $\alpha$

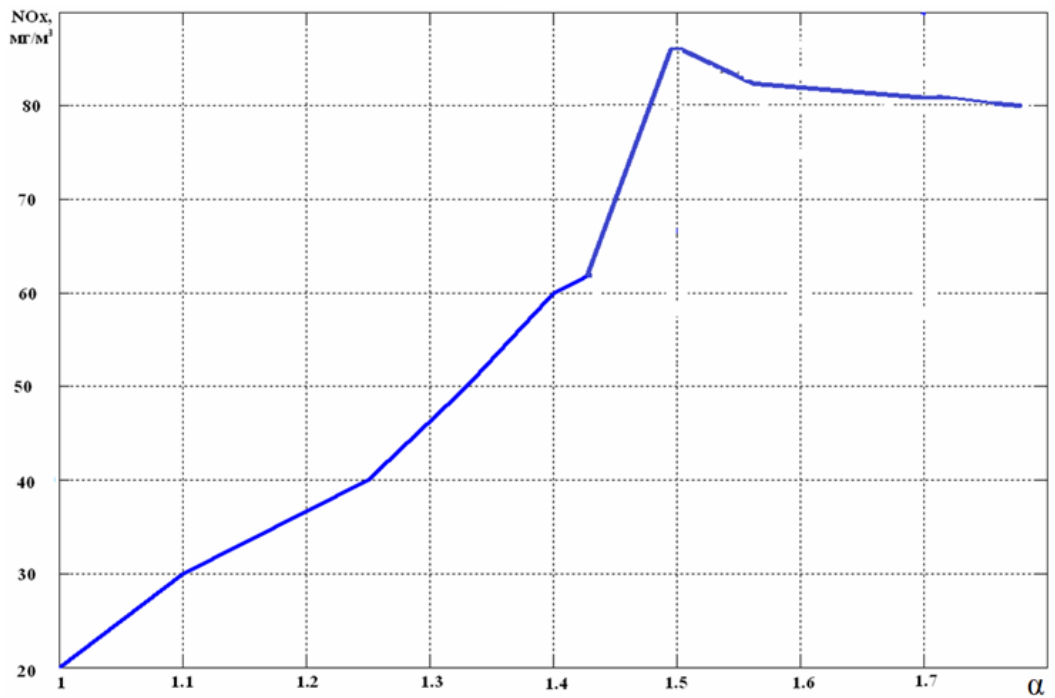

Рис. 4. Залежність вмісту $\mathrm{NO}_{\text {в }}$ димових газах котла ГМ-50 від значення $\alpha$

При подальшому збільшенні $\alpha$ спостерігається надмірна кількість кисню та азоту в зоні реакції. Це повинно було б сприяти збільшенню концентрації NO в продуктах згоряння. Але на нагрів надлишку $\mathrm{O}_{2} \mathrm{i}$ $\mathrm{N}_{2}$ витрачається теплота, що виділяється в ході окислення вуглеводів, 
тобто горіння. Це призводить до зниження середнього температурного рівня факела, а отже, до зниження концентрації NO.

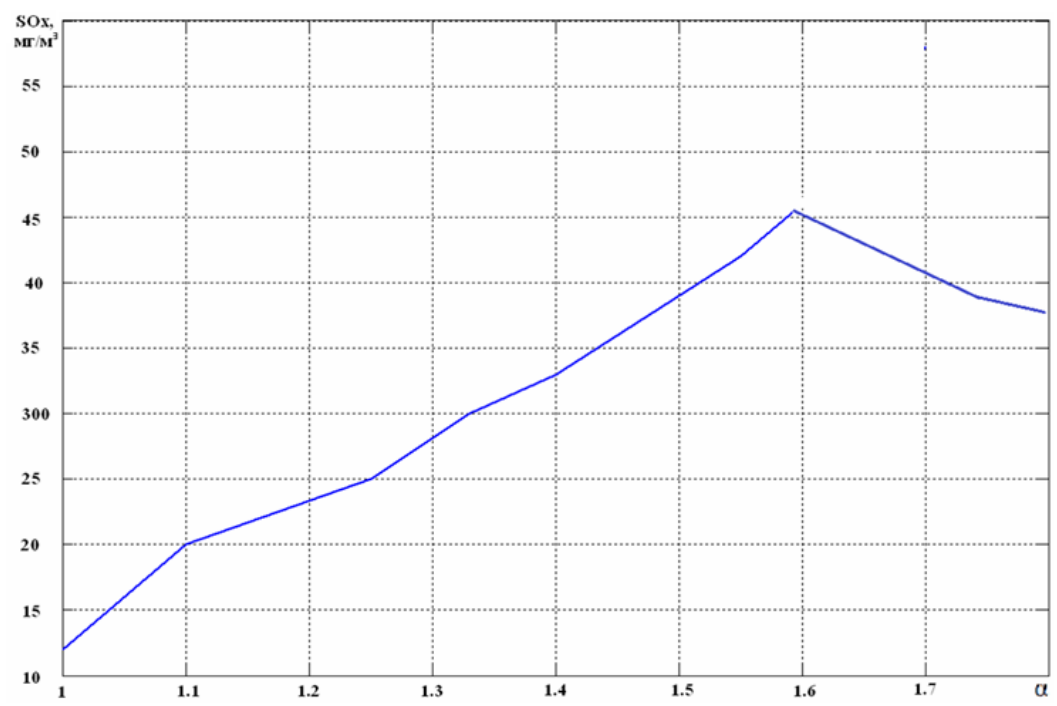

Рис. 5. Залежність вмісту $\mathrm{SO}_{\mathrm{x}}$ в димових газах котла ГМ-50 від коефіцієнта надлишку повітря $\alpha$

Таким чином, для зниження вмісту шкідливих викидів СПУ необхідно зниження значення $\alpha$. Залежності концентрації шкідливих викидів від режимів роботи промислового парового котла і його управляючих елементів враховані в процесі навчання нейромережевої системи моніторингу (НМ) вмісту шкідливих викидів від СПУ.

Розробка такої системи може дозволити оптимізувати екологічну складову процесу горіння. В умовах, запиту від оператора коли до акваторії знаходження судна пред'являються суворі обмеження щодо вмісту шкідливих викидів, нейромережева система, відповідно до своєї навчальної вибірки, отриманої за допомогою експериментальних даних (рис. 1 - 5), видає рекомендації оператору котла щодо вибору і підтримці оптимального $\alpha$ і заданих швидкостей обертання повітряного вентилятора і димососа СПУ, що забезпечує зниження $\mathrm{NO}_{\mathrm{x}}$ i $\mathrm{SO}_{\mathrm{x}}$.

Останнім часом були розроблені прилади з використанням твердотільних датчиків, які здатні швидко і відтворено вимірювати вміст $\mathrm{CO}, \mathrm{O}_{2}$ в димових газах. Особливістю одного з таких газоаналізаторів, розробленого за участю фахівців компанії «Інформаналітіка» [6] є ви- 
користання керамічних сенсорів, що визначають зміст $\mathrm{CO}$ і $\mathrm{O}_{2}$ при температурах аналізованого газу до $1000{ }^{\circ} \mathrm{C}$ та дозволяють використовувати схему динамічного відбору проби (рис. 6).

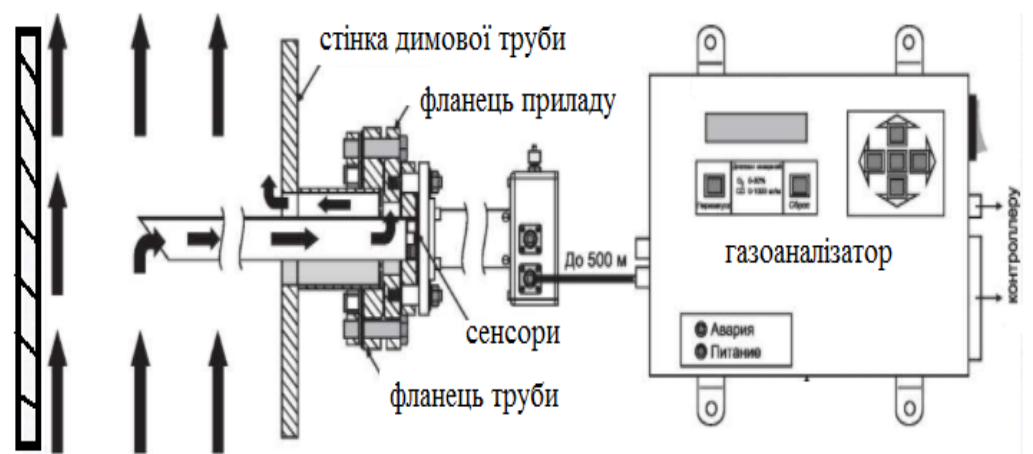

димові гази

Рис. 6. Схема відбору димових газів для газоаналізатору котла

Використання пропонованого для СПУ методу динамічного відбору проби дозволить істотно спростити і знизити вартість системи, що призводить до її ефективного використання для котлів невисокої потужності. Обмеження у використанні методу динамічного відбору проби - швидкість потоку, при якій забезпечується надійна подача проби до сенсорів. Як показано [6], достатньою $є$ швидкість газового потоку 2 м/с. Поєднання динамічного відбору проби і використання високотемпературних сенсорів дозволяє позбутися проблем, які пов'язані з конденсацією продуктів горіння в системі відбору проби, i, крім того, істотно збільшує швидкодію системи в цілому. Передача даних від первинного перетворювача до блоку індикації здійснюється за допомогою інтерфейсу RS-485. Блок індикації дозволяє зчитувати поточні значення концентрації $\mathrm{CO}$ і $\mathrm{O}_{2}$, крім цього, він служить для формування керуючих струмових сигналів $4-20$ мА. Відстань, на яке може бути віднесений блок індикації від місця монтажу пробовідбірних пристроїв та первинного перетворювача, досягає 500 м.

Виходячи $з$ експериментальних даних на представлених вище діаграмах, була навчена нейронна мережа для системи моніторингу щодо оптимізації процесу управління СПУ, тобто процесу горіння палива 3 метою зниження вмісту шкідливих викидів в атмосферу. Апробація нейронної мережі, що доповнює діючу суднову систему моніторингу, 
здійснена для наступних умов: «У випадках, якщо вимоги щодо акваторії знаходження судна до вмісту оксидів азоту в атмосфері, наприклад $\mathrm{NO}_{\mathrm{x}}=$ до 48 мг / ${ }^{3} »$, тоді НМ за запитом оператора (рис. 7) видає необхідні значення коефіцієнта надлишку повітря, навантаження СПУ, швидкості газів: $\alpha=1,3 ; P_{\text {н }}=40 \%$ від номінальної; швидкість газів $v=4 \mathrm{~m} / \mathrm{c}$, тобто двигун димососа рециркуляції димових газів, підключений до частотного перетворювача, починає розвивати задані оберти за сигналом, що отриманий від оператора (також оператор СПУ має дистанційно контролювати баланс розрядження в топці і стійкість горіння факела пальника). Ці значення встановлюватися як задані для регулятора в САУ горіння палива СПУ з метою оптимізації процесу за критеріями мінімізації шкідливих викидів (рис. 8).

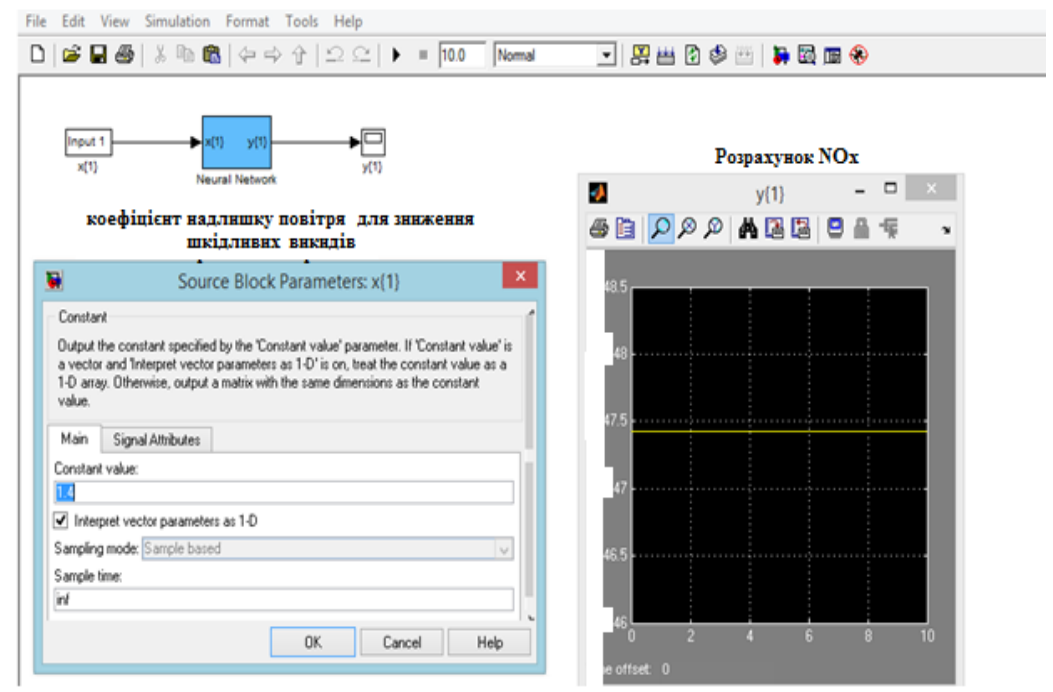

Рис. 7. Програма роботи $\mathrm{HM}$, що визначає значення $\mathrm{NO}_{\mathrm{x}}$ при заданому $\alpha$

Навчання нейронної мережі було проведено в програмі Matlab (Neural Networks Toolbox).

3 метою визначення адекватності експериментальної вибірки НМ проведено теоретичний аналіз залежності впливу режимів роботи СПУ на вміст $\mathrm{NO}_{\mathrm{x}}$ у вихідних газах. Розрахунок виконаний за допомогою методики [9].

Сумарна кількість оксидів азоту $\mathrm{NO}_{\mathrm{x}}$ в перерахунку на $\mathrm{NO}_{2}$ (в $\Gamma / \mathrm{c}$, т/рік), що викидаються в атмосферу з димовими газами 


$$
M_{\mathrm{NOx}}=B_{\mathrm{T}} \cdot Q_{i}^{r} \cdot K_{\mathrm{NO} 2}{ }^{\mathrm{M}} \cdot \beta_{t} \cdot \beta_{\alpha} \cdot k_{\mathrm{\Pi}},
$$

де $B_{\text {т }}$ - фактична витрата палива на котел кг/с (т/год); $Q_{i}^{r}-$ нижча теплота згоряння палива, МДж/кг; $K_{\mathrm{NO} 2}{ }^{\mathrm{M}}-$ питомий викид оксидів азоту при спалюванні мазуту, г/МДж, пдля парових СПУ

$$
K_{\mathrm{NO}_{2}}^{\mathrm{M}}=0,01 \cdot \sqrt{D}+0,1,
$$

$D$ - фактична паропродуктивність котла, т/ч; $\beta_{t}$ - безрозмірний коефіцієнт, який враховує температуру повітря, що подається,

$$
\beta_{t}=1+0,002 \cdot\left(t_{\mathrm{rв}}-30\right),
$$

$t_{\text {гв }}-$ температура гарячого повітря, ${ }^{\circ} \mathrm{C} ; \beta_{\alpha}-$ безрозмірний коефіцієнт, що враховує вплив надлишку повітря на утворення оксидів азоту при спалюванні рідкого палива; $k_{\text {п }}$ - коефіцієнт перерахунку (при визначенні викидів в грамах в секунду $k_{\text {п }}=1$, при визначенні викидів в тонах в рік $k_{\text {пा }}=10^{-3}$ ).
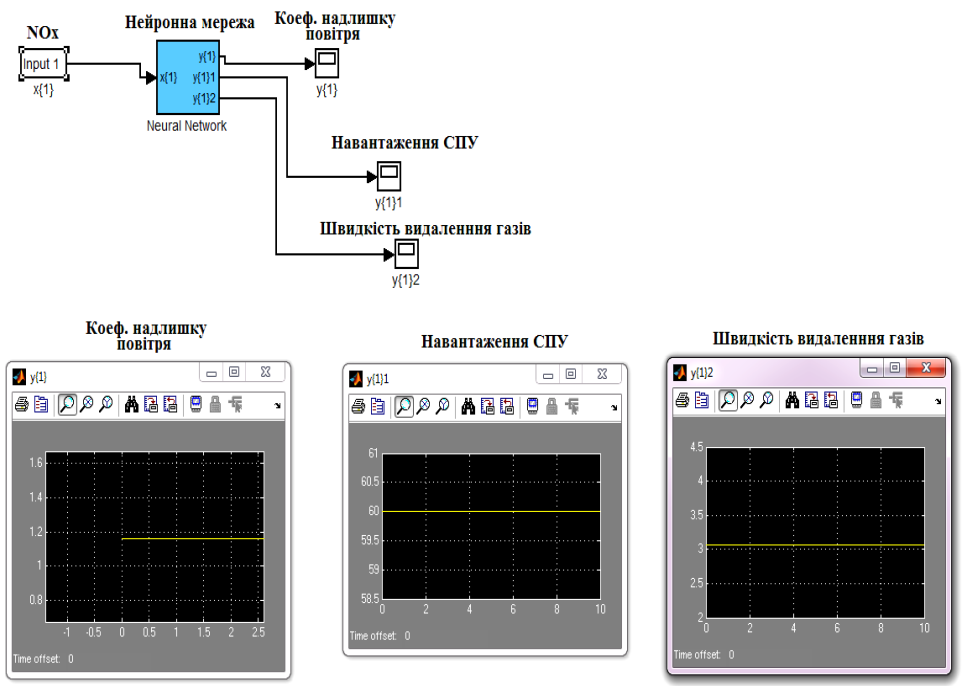

Рис. 8. Моделювання нейромережевої системи моніторингу $\mathrm{NO}_{\mathrm{x}}$

В залежності від режиму СПУ значення $\beta_{\alpha}=1,11-1,45$ (фактично рівний $\alpha$ ). Зниження коефіцієнту $\beta_{\alpha}$ (тобто зменшення викидів $\mathrm{NO}_{\mathrm{x}}$ ) за рахунок зниження концентрації кисню $\mathrm{O}_{2}$, обмежується зростанням концентрації СО понад 0,01\%. Проте збільшувати концентрацію кисню $\mathrm{O}_{2}$ для зниження $\beta_{\alpha}$ не рекомендується через зростання втрат з газами $q_{2}[6,7]$. 
Слід зазначити, що залежність (3) не відображає повною мірою вміст оксидів азоту в димових газах від теплової навантаження котла i коефіцієнта надлишку повітря, що викликає труднощі для іiї використання в САУ оптимізації показників шкідливих викидів з урахуванням теплового навантаження СПУ.

За результатами проведення експериментів отримана емпірична формула залежності змісту оксидів азоту від експлуатаційних параметрів СПУ:

$$
C_{N O_{x}}=\frac{O_{2}}{P_{n}} R_{N_{2}} \frac{D_{T}}{D_{\text {д.г }}},
$$

де $\mathrm{O}_{2}$ - вміст кисню в димових газах котла, $\% ; P_{n}$ - теплове наванта-

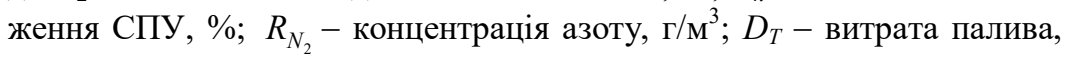
кг/год; $D_{\text {д.г }}-$ витрата димових газів, кг/год.

Урахування формули (4) в програмі регулятора САУ горіння палива в СПУ дозволяє здійснити зниження значення оксидів азоту шляхом збільшення витрати димових газів (швидкості обертання димососу газів і вентилятора повітря) або шляхом зниження вмісту кисню (зниження коефіцієнта надлишку повітря) без зниження парової завантаження.

На рис. 9 показані результати розрахунку за формулою (4) і дані, що отримані під час проведення експерименту. В розрахунку використовувалися паспортні дані СПУ Мітсубіші МАС-35 (рис. 10).

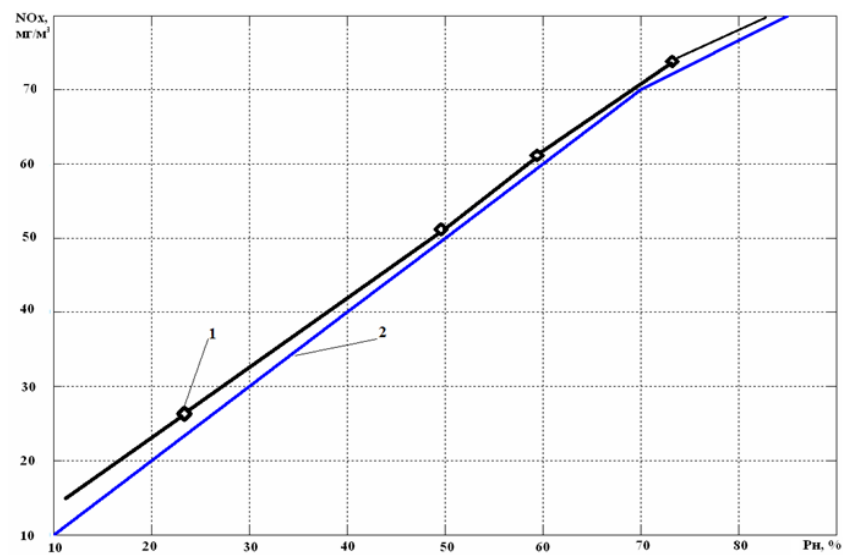

Рис. 9. Залежності вмісту оксидів азоту від теплового навантаження парового котла: 1 - експериментальна; 2 - аналітична 
Як видно з рис. 9 запропонована емпірична формула (4) дозволяє 3 великою вірогідністю прогнозувати зміни концентрації оксидів азоту в залежності від теплового завантаження допоміжних СПУ широкого конструктивного класу.

Згідно даних [10] при навантаженні СПУ МАС-35 50 \%, приймаються наступні вихідні значення: $B_{\text {т }}=0,35$ кг $/ \mathrm{c} ; Q_{i}=43$ МДж/кг (тяжке паливо); $K_{\mathrm{NO} 2}{ }^{\mathrm{M}}=0,12 \mathrm{\kappa г} / \mathrm{c} ; \beta_{t}=1,08 ; \beta_{\alpha}=1,16$. Для представлених значень $M_{\mathrm{NOx}}$ буде рівна $2,26 \mathrm{Mr} / \mathrm{c}$.

\begin{tabular}{|c|c|c|c|c|c|}
\hline \multicolumn{2}{|l|}{ Навантаження } & $25 \%$ & $50 \%$ & $75 \%$ & $100 \%$ \\
\hline Парова продуктивність & $\mathrm{kg} / \mathrm{h}$ & 8,750 & 17,500 & 26,250 & 35,000 \\
\hline Тиск у барабані & $\mathrm{kg} / \mathrm{cm}^{2}$ & 16.0 & 16.0 & 16.0 & 16.0 \\
\hline Температура живлячої води & $\operatorname{deg} . \mathrm{C}$ & 80.0 & 80.0 & 80.0 & 80.0 \\
\hline Температура насиченого пару & $\operatorname{deg} \mathrm{C}$ & 203.4 & 203.4 & 203.4 & 203.4 \\
\hline Кк, & $\%$ & 82.1 & 82.8 & 81.9 & 80.5 \\
\hline $\begin{array}{l}\text { Теплова } \\
\text { продук- }\end{array}$ & $\mathrm{kcal} / \mathrm{kg}$ & 10,280 & 10,280 & 10,280 & 10,280 \\
\hline тивність & $\mathrm{kcal} / \mathrm{kg}$ & 9,713 & 9,713 & 9,713 & 9,713 \\
\hline Споживання мазута & $\mathrm{kg} / \mathrm{h}$ & 644 & 1,277 & 1,937 & 2,628 \\
\hline $\begin{array}{l}\text { Надлишкове споживання } \\
\text { повітря }\end{array}$ & $\%$ & 31 & 16 & 15 & 15 \\
\hline BMict O2 & $\%$ & 5.0 & 3.0 & 2.9 & 2.9 \\
\hline $\begin{array}{l}\text { Споживання приточного } \\
\text { повітря }\end{array}$ & $\mathrm{kg} / \mathrm{h}$ & 11,820 & 20,740 & 31,190 & 42,320 \\
\hline Споживання димових газів & $\mathrm{kg} / \mathrm{h}$ & 12,460 & 22,020 & 33,130 & 44,940 \\
\hline $\begin{array}{l}\text { Температура } \\
\text { навколишнього середовища }\end{array}$ & $\operatorname{deg} . \mathrm{C}$ & 45 & 45 & 45 & 45 \\
\hline
\end{tabular}

Рис. 10. Робочі параметри суднового котла Mitsubishi MAC-35 B (режимна карта) [10]

3 урахуванням рекомендацій нейронної мережі щодо зниження $\mathrm{NO}_{\mathrm{x}}$, тобто підтриманню $\alpha$, вираженому в виді $\beta_{\alpha}=1,11$ і одночасному збільшенню швидкості проходження димових газів згідно зниженню їх температури - $\beta_{t}=1,02$, вміст $\mathrm{NO}_{\mathrm{x}}$ складе $1,70 \mathrm{M \Gamma} / \mathrm{c}$. У даному випадку розрахунки показали, що використання НМ на прикладі одного найбільш розповсюдженого режиму СПУ дозволяє знизити $\mathrm{NO}_{\mathrm{x}}$ на $0,56 \mathrm{мг} / \mathrm{c}$ або $25 \%$.

Результати моделювання показали, що використання нейромережевої системи моніторингу димових газів промислового мазутного 
котла ГМ-50 і суднового котла МАС-35 дозволяє знизити вміст $\mathrm{NO}_{\mathrm{x}}$, приблизно на 25 \% в порівнянні з типовою системою управління, яка не оснащена димососом з частотним приводом і системою моніторингу. Можна зробити висновок що використання запропонованої системи дозволяс знизити вміст шкідливих викидів СПУ в атмосферу без значних витрат на технологічне переоснащення судна.

\section{ЛИТЕРАТУРА REFERENCES}

1. Электроэнергетика и охрана окружающей среды. Функционирование энергетики в современном мире [Электронный ресурс]. http://energetika.in.ua/ru/books/book-5/intro.

2. Хачоян М.М. Снижение выбросов оксидов азота с отработавшими газами судовых дизелей и котлов абсорбцией водой: дис. ... канд. техн. наук. - 05.08.05. - Новороссийск: ФГБОУ ВПО "Государственный морской университет имени адмирала Ф.Ф. Ушакова", 2014. $-185 \mathrm{c}$.

3. Михайленко В.С. Усовершенствование системы управления рециркуляцией дымовых газов судового вспомогательного котла [Текст] / В.С. Михайленко, В.Ф. Ложечников // Автоматизация судовых технических средств: науч.- техн. сб. - 2019. - Вып. 25. - Одесса: НУ «OMA». - C. $53-62$.

4. Сыромятников В.Ф. Наладка автоматики судовых энергетических установок / В.Ф. Сыромятников. - Санкт-Петербург: Судостроение, 2009. $-352 \mathrm{c}$.

5. Техническая документация по эколого-теплотехническим испытаниям котлоагрегата ГМ-50-15/250, ст. № 3 (топливо: мазут) / “ОДЕССАЭНЕРГОНАЛАДКА”. - Одесса, 2016. - 56 с.

6. Газоанализаторы для оптимизации режимов горения топлива. URL: http://www.infogas.ru/22_NT_4_2015.

7. Хряпченков А.С. Судовые вспомогательные и утилизационные котлы. - Л.: Судостроение, 1988. - 296 с.

8. Зельдович Я.Б., Семенов Н.Н. Теория горения и детонации газов. - М.: Академия наук СССР. Институт химической физики, 1944. $-70 \mathrm{c}$.

9. Методические указания по расчету выбросов оксидов азота с дымовыми газами котлов тепловых электростанций: СО 15334.02.304-2003, https://files.stroyinf.ru/Data2/1/4294814/4294814036.htm. 
Аннотация - Рассмотрены вопросы снижения содержания оксидов азота и серы в дымовых газах паровых котлов с помощьюю предлагаемой нейросетевой системы мониторинга содержания вредных выбросов в дымовых газах.

На основе проведенных экспериментов на промышленном водотрубном мазутном котле ГМ-50 (аналоге CПУ Mitsubishi MB 50) u экспериментальных данных в виде графических характеристик, отражающих зависимости содержания оксидов азота, серы и монооксида углерода, получены значения для обучения нейросетевой системы мониторинга проиесса выброса вредных газов в атмосферу. В процессе проведенных экспериментов было установлено, что при снижении тепловой нагрузки котла до 0,5 от номинального и стабилизации коэффициента избытка воздуха, содержание оксидов азота в уходящих газах снижается в среднем до 30\%. Также было установлено, что снижение скорости прохождения дымовых газов на один м/с (за счет плавного увеличения оборотов двигателя дымососа) снижает содержание оксидов азота в среднем на десять мг/м3 по сравнению с дымососом рециркуляиии, работающим на одной скорости. Также, в ходе экспериментов, был установлен и рост содержания оксидов серы в уходящих газах при увеличении коэффициента избытка воздуха в дымовых газах. Многочисленные исследования показали, что между кониентраџией монооксидов азота и тепловой мощзностью агрегата в диапазоне рабочих нагрузок существует линейная зависимость. Использование обученной нейросети в системе мониторинга может позволить достичь минимально возможного содержания значений оксидов азота и серы при нахождении судна в зоне контроля вредных выбросов. Имитационное моделирование предлагаемой нейростетвой системы проведено в специализированной программе Matlab (Neural Networks Toolbox).

Результаты моделирования показали, что использование нейросетевой системы мониторинга содержания вредных выбросов в дымовых газах промышленного водотрубного барабанного котла ГМ-50 М работающем на мазуте позволяет снизить содержание оксидов азота, по предварительным расчетам, на $25 \%$ по сравнению с типовой системой реииркуляции, не оснащенной дымососом с частотным приводом.

Анотація - Розглянуто питання зниження вмісту оксидів азоту $i$ сірки в димових газах парових котлів за допомогою запропонованої нейромережевої системи моніторингу вмісту шкідливих викидів в димових газах. 
На основі проведених експериментів на промисловому водотрубному мазутному котлі ГМ-50 (аналог СПУ Mitsubishi MB 50) і ексnериментальних даних у вигляді графічних характеристик, щзо відображають залежності змісту оксидів азоту, сірки і монооксиду вуглецю, отримані значення для навчання нейромережевої системи моніторингу процесу викиду шкідливих газів в атмосферу. У прочесі проведених експериментів було встановлено, що при зниженні теплового навантаження котла до 0,5 від номінального і стабілізачії коефіиієнта надлишку повітря, вміст оксидів азоту в газах знижується в середньому до 30\%. Також було встановлено, що зниження швидкості проходження димових газів на один м/с (за рахунок плавного збільшення оборотів двигуна димососа) знижуе вміст оксидів азоту в середньому на десять мг/м3 у порівнянні з димососом рециркуляиії, працюючим на одній швидкості. Також, в ході експериментів, був встановлений i факт зростання вмісту оксидів сірки в газах при збільшенні коефіцієнта надлишку повітря в димових газах. Численні дослідження показали, щзо між конщентрацією монооксиду азоту і тепловою потужністю агрегату в діапазоні робочих навантажень існує лінійна залежність. Використання навченої нейромережі в системі моніторингу може дозволити досягти мінімально можливого змісту значень оксидів азоту і сірки при знаходженні судна в зоні контролю шкідливих викидів. Імітаційне моделювання запропонованої нейромережевої системи проведено в спечіалізованій програмі Matlab (Neural Networks Toolbox).

Результати моделювання показали, що використання нейромережевої системи моніторингу вмісту шкідливих викидів в димових газах промислового водотрубного барабанного котла ГМ-50 М, який праиює на мазуті, дозволяє знизити вміст оксидів азоту за попередніми розрахунками, на 25\% в порівнянні з типовою системою рециркуляиї, щзо не оснащена димососом з частотним приводом.

Annotation - The issues of reducing the content of nitrogen and sulfur oxides in the flue gases of steam boilers using the proposed neural network system for monitoring the content of harmful emissions in flue gases are considered.

Based on the experiments carried out on the industrial water-tube fuel oil boiler GM-50 (analogue of the Mitsubishi MV 50 SPU) and experimental data in the form of graphical characteristics reflecting the dependences of the content of nitrogen oxides, sulfur and carbon monoxide, values were obtained for training a neural network system for monitoring the emission of harmful gases in atmosphere. In the course of the experiments, it was 
found that when the heat load of the boiler is reduced to 0.5 from the nominal and the excess air ratio is stabilized, the content of nitrogen oxides in the exhaust gases decreases to an average of $30 \%$. It was also found that a decrease in the speed of passage of flue gases by one $\mathrm{m} / \mathrm{s}$ (due to a smooth increase in the speed of the exhaust fan motor) reduces the content of nitrogen oxides by an average of ten $\mathrm{mg} / \mathrm{m} 3$ in comparison with a recirculation fan operating at the same speed. Also, in the course of the experiments, an increase in the content of sulfur oxides in the flue gases was established with an increase in the excess air ratio in the flue gases. Numerous studies have shown that there is a linear relationship between the concentration of nitrogen monoxides and the heat output of the unit in the range of operating loads. The use of a trained neural network in a monitoring system can make it possible to achieve the minimum possible content of nitrogen and sulfur oxides when the vessel is in the emission control zone. Simulation modeling of the proposed neural system was carried out in a specialized program Matlab (Neural Networks Toolbox).

The simulation results showed that the use of a neural network system for monitoring the content of harmful emissions in the flue gases of an industrial water-tube drum boiler GM-50 M operating on fuel oil makes it possible to reduce the content of nitrogen oxides, according to preliminary calculations, by 25\% compared to a typical recirculation system not equipped with a smoke exhauster with frequency drive. 